\title{
Hypoglycemic Potential of Aqueous Extracts of Ageratum Conyzoides L., Anthocleista Djalonensis A. Chev. and Bidens Pilosa L., Three Plants from the Ivorian Pharmacopoeia
}

\author{
Arthur Stephane Gnagne, \\ Laboratory of Botany, University Felix Houphouët-Boigny, \\ Abidjan, Côte d'Ivoire \\ Kiyinlma Coulibaly, \\ Faculty of Biological Sciences, University Péléforo Gon Coulibaly, \\ Korhogo, Côte d'Ivoire \\ N'Guessan Bra Yvette Fofie, \\ Faculty of Pharmaceutical and Biological Sciences, \\ University of Felix Houphouët-Boigny, Abidjan, Côte d'Ivoire.

\section{Kouadio Bene,} \\ Guede Noel Zirihi, \\ Laboratory of Botany, University Felix Houphouët-Boigny, \\ Abidjan, Côte d'Ivoire
}

Doi: 10.19044/esj.2018.v14n12p360 URL:http://dx.doi.org/10.19044/esj.2018.v14n12p360

Abstract

Ageratum conyzoides L. (Asteraceae), Anthocleista djalonensis A. Chev. (Gentianaceae) and Bidens pilosa L. (Asteraceae) are three plants used in traditional medicine to treat diabetes. The objective of this present study was to investigate the hypoglycemic potential of the aqueous extracts of these three plants, in order to justify their use by traditional healers. Each extract and both control substances were administered at a single dose to animals by gavage using a catheter for each concentration $(70,90$ and $110 \mathrm{mg} / \mathrm{ml})$, at the recommended dose $(2 \mathrm{ml} / 100 \mathrm{~g}$ of b.w). The search for the hypoglycemic effect of the aqueous extract of each plant in normal glycemic rats given orally showed a decrease in blood glucose. The aqueous extract of Bidens pilosa induces a significant dose-dependent hypoglycaemia. The phytochemical study has revealed the presence of polyphenols, flavonoids, tannins (catechins and gallic), saponosides and alkaloids, compounds with multiple medical properties, including glycemic regulation in diabetics. The study revealed that the aqueous extracts of the three plants have a hypoglycemic potential with the aqueous extract of Bidens pilosa showing better activity, the results of our 
investigation justify their use in traditional medicine in the treatment of diabetes.

Keywords: Ageratum conyzoides, Anthocleista djalonensis, Bidens pilosa, hypoglycemic potential, diabetes

\section{Introduction}

The use of medicinal plants is widespread and of increasing health and economic importance. Herbal treatment is used for the treatment of several diseases, including diabetes, which is the most common endocrine disease (N'Doua et al., 2015). Diabetes is a multifactorial chronic condition that results in high blood sugar levels. The normal value of fasting blood glucose is 0.8 to 1.2 grams per litre. Below these values, one is in hypoglycaemia state, and above one is in hyperglycaemia state. This metabolic abnormality is due to insufficient or inappropriate use of insulin by the body (Ghourri et al., 2013).

In Côte d'Ivoire, the International Diabetes Federation (IDF) estimated in 2014 the prevalence of diabetes mellitus at $9.6 \%$, which is a major public health problem (Kroa et al., 2016). The therapeutic management of diabetes is currently based on strict dieting and the use of oral antidiabetic drugs. This solution is obviously expensive given the low purchasing power of the population in most developing countries like Côte d'Ivoire. Diabetes and its complications have significant socioeconomic consequences. This disease can damage blood vessels, nerves, eyes and kidneys. Diabetes can lead to high blood pressure and disrupt cardiac activity. Currently, diabetes therapy is based on the use of synthetic hypoglycaemic compounds (sulfonamides, biguanides and insulin), diet and physical exercise measures (N'Guessan et al., 2011). Even though insulin injections or other products keep the diabetic patient alive, diabetes requires a continuous and expensive treatment that patients in most cases cannot afford. The high costs of conventional treatments oblige diabetic patients to take to traditional remedies (WHO, 2011). In addition, the medical treatment management of diabetes is limited due to the fact certain populations have no access to medical facilities. In such situation, people often take to medicinal plants for treatment (Fah et al., 2013). The traditional pharmacopoeia offers treatment that is cheap and affordable to the majority of the population (Ndomou et al., 2014). In addition, antidiabetic herbal medicine is currently experiencing a significant growth due to the growing discovery of effective plant extracts in the treatment of diabetes (Jayakar and Suresh, 2003). Note that the use of plant extracts is a common practice in African Traditional Medicine. These traditional therapies with unknown chemical compositions and pharmacological properties are more and more proposed to diabetics. It therefore seems essential for scientists to carry out ethnobotanical, phytochemical and pharmacological studies in order to 
justify the therapeutic virtues granted to these preparations. In the light of all the results obtained, Improved Traditional Medicines accessible to all will be made available to the population. With this in mind, WHO recommends that the quality, safety and efficacy of medicinal plants and improved traditional medicines be evaluated (WHO, 2002). It is in line with this understanding that our study was carried out, having as main objective to evaluate the hypoglycaemic potential of the aqueous extracts of three medicinal plants selected at the end of an ethnobotanical survey. This survey was carried out in the region of Zuenoula.

\section{Material}

\section{Plant material}

Consisted of three plants selected from the ethnobotanical survey. They are: Ageratum conyzoides L. (Asteraceae), Anthocleista djalonensis A. Chev. (Gentianaceae) and Bidens pilosa L. (Asteraceae).

\section{Animal material}

The tests were performed using male and female, white, albino rats, normoglycemic of the species Ratus norvegicus. These adult rats age 12 to 16 weeks old and had a body mass of between $180 \mathrm{~g}$ and $200 \mathrm{~g}$. These animals were fed with FACI ${ }^{\circledR}$ pellets and water. They were acclimatized in the cages for two weeks to get used to them.

\section{Method}

\section{Preparations of aqueous extracts of selected plants}

The respective plant organs collected were rinsed with water and dried away from the sun (at room temperature). They are: Ageratum conyzoides (leafy twigs), Anthocleista djalonensis (stem bark) and Bidens pilosa (leafy twigs). These dried plant organs were then reduced to powder using an electric grinder IKA-MAG RTC. A fine powder was obtained. The method of Zirihi et al. (2003) was used to extract the active ingredients. One hundred grams (100 g) of drug powder was homogenized in 1 litre of distilled water in a Life's Superb brand blender (Mixer) (LS-317) for three minutes (repeated twice) at room temperature. The homogenate obtained was filtered successively on a square of white fabric, on hydrophilic cotton and then on Wattman paper. Using an oven set at $50^{\circ} \mathrm{C}$, the extraction solvent was removed. The dry evaporate was recovered as a powder and constituted the total aqueous extract.

\section{Extraction yield calculation}

The extract yield is the amount of extract obtained from the vegetable powder. It is expressed as a percentage or is without a unit. In practice, it is determined by the ratio of the weight of the dry extract after evaporation to the 
weight of the powder of dried plant material used for the extraction, multiplied by 100 . This is summarized in the following formula:

$$
\operatorname{Rd}(\%)=\frac{m}{M} \times 100
$$

(Rd: extraction yield in percentage, $\mathrm{m}$ : mass in gram of the dry extract, $\mathrm{M}$ : mass in gram of the drug powder).

\section{Phytochemical Screening}

A phytochemical screening was carried out in order to highlight some large groups of secondary metabolites contained in the various aqueous extracts tested and responsible for possible activities. Screening by colour reactions was used (Mangambu et al., 2014).

\section{Hypoglycemic activity}

Investigating the hypoglycemic effect of the aqueous extract of each of the plants in normoglycemic rats in a single-dose at a concentration of $90 \mathrm{mg}$ / ml

It is about verifying the hypoglycemic activity of each plant extract as used in the traditional medicine.

In order to investigate with a range of three concentrations, a single dose test at concentration of $90 \mathrm{mg} / \mathrm{ml}$ was initiated. This would enable us to fix the concentration range according to the results obtained. This experiment was inspired by the work done by Lebri (2016).

Thirty rats divided into five lots of six rats each were used:

- Lot 1 (negative control) received orally distilled water according to the body weight of the animal,

- $\quad$ Lot 2 received orally glibenclamide (reference antidiabetic substance) at a concentration of $0.25 \mathrm{mg} / \mathrm{ml}$,

- $\quad$ Test lot1 received by gavage the total aqueous extract of Ageratum conyzoides (AGECO) at a single dose of $90 \mathrm{mg} / \mathrm{ml}$,

- $\quad$ Test lot 2 received by gavage the total aqueous extract of Bidens pilosa (BIDPI) at a single dose of $90 \mathrm{mg} / \mathrm{ml}$,

- $\quad$ Test lots 3 received by gavage the total aqueous extract of Anthocleista djalonensis (ANTDJ) at a single dose of $90 \mathrm{mg} / \mathrm{ml}$.

Investigating the hypoglycemic effect of the aqueous extract of each plant in normoglycemic rats at different concentrations

Each extract and both control substances were administered by gavage at a single dose to the animals using a catheter at the recommended dose $(2 \mathrm{ml}$ / $100 \mathrm{~g}$ of b.w) according to OCDE (2001) for each concentration. The blood glucose monitoring in the rats was done in the short term for 4 hours. The rats 
fasted for 18 hours and then the lots were formed. The rats' blood sample were taken before oral administration (gavage) of the test substances. This is the basic blood glucose (fasting glucose) for each lot. For the experiment, 54 rats divided into nine lots of six rats each. They are normoglycemic rats:

- $\quad$ Lots $3 \mathrm{a}, 3 \mathrm{~b}$ and $3 \mathrm{c}$ received by gavage the total aqueous extract of AGECO at a concentration of 70, 90 and $110 \mathrm{mg} / \mathrm{ml}$ respectively,

- $\quad$ Lots $4 \mathrm{a}, 4 \mathrm{~b}$ and $4 \mathrm{c}$ received, by gavage, the total aqueous extract of BIDPI at a concentration of 70,90 and $110 \mathrm{mg} / \mathrm{ml}$ respectively,

- $\quad$ Lots $5 \mathrm{a}, 5 \mathrm{~b}$ and $5 \mathrm{c}$ received by gavage the total aqueous extract of ANTDJ at the concentration of 70,90 and $110 \mathrm{mg} / \mathrm{ml}$ respectively.

After administration of the test substances, the blood sample was taken every hour for 4 hours from the thirtieth minute.

\section{Results}

\section{Extraction Yield}

The extractions made it possible to obtain different aqueous extracts of the three selected plants. The yields are shown in Table 1.

According to this table, the best extraction yield is obtained with the total aqueous extract of Ageratum conyzoides (18\%). The lowest yield is obtained with the total aqueous extract of Anthocleista djalonensis (13\%).

Table 1: Yield of the various aqueous extracts

\begin{tabular}{|c|c|c|c|}
\hline & $\begin{array}{c}\text { Extracts } \\
\text { Quantity of initial } \\
\text { drug powder }(\mathrm{g})\end{array}$ & $\begin{array}{c}\text { Quantity of extract } \\
\text { obtained after } \\
\text { extraction }(\mathrm{g})\end{array}$ & Average Yield (\%) \\
\hline Plantes & 600 & 108 & 18 \\
\hline BGECO & 600 & 90 & 15 \\
\hline ANTDI & 400 & 52 & 13 \\
\hline
\end{tabular}

Key:

AGECO : Ageratum conyzoides

BIDPI : Bidens pilosa

ANTDJ : Anthocleista djalonensis

\section{Phytochemical Screening}

To justify the different activities observed, a characterization of phytochemicals was carried out. It focused on the search for seven groups of chemical compounds they are: polyphenols, tannins (catechics and gallic), saponins, flavonoids, sterols and polyterpenes, alkaloids and quinones). Table 2 summarizes the results of the phytochemical screening of the various extracts.

Ageratum conyzoides contains polyphenols, saponosides, flavonoids, sterols and polyterpenes and alkaloids. The aqueous extract of Bidens pilosa contains compounds such as polyphenols, catechin tannins and saponosides. 
Anthocleista djalonensis contains flavonoids, tannins, saponosides and alkaloids. None of these aqueous extracts contain Quinones.

Table 2: Different Group of Chemical Compounds in Plants

\begin{tabular}{|c|c|c|c|c|c|c|c|c|c|}
\hline \multirow{2}{*}{$\begin{array}{l}\text { Compo } \\
\text { und } \\
\text { Plantes }\end{array}$} & \multirow{2}{*}{$\begin{array}{l}\text { Sterols et } \\
\text { polyterpe } \\
\text { nes }\end{array}$} & \multirow{2}{*}{$\begin{array}{l}\text { Polyphen } \\
\text { ols }\end{array}$} & \multirow{2}{*}{$\begin{array}{c}\text { Flavono } \\
\text { ids }\end{array}$} & \multicolumn{2}{|c|}{ Tanins } & \multirow{2}{*}{$\begin{array}{l}\text { Quino } \\
\text { nes }\end{array}$} & \multirow{2}{*}{$\begin{array}{l}\text { Saponosi } \\
\text { des }\end{array}$} & \multicolumn{2}{|c|}{$\begin{array}{c}\text { Alkaloi } \\
\text { ds }\end{array}$} \\
\hline & & & & $\begin{array}{l}\mathrm{Ca} \\
\text { t. }\end{array}$ & $\begin{array}{c}\mathrm{Ga} \\
1 .\end{array}$ & & & B & D \\
\hline $\begin{array}{c}\text { AGEC } \\
\text { O }\end{array}$ & + & + & + & - & - & - & + & + & + \\
\hline BIDPI & - & + & - & + & - & - & + & - & - \\
\hline ANTDJ & + & + & + & + & + & - & + & + & + \\
\hline
\end{tabular}

Key:

AGECO : Ageratum conyzoides

BIDPI : Bidens pilosa

ANTDJ : Anthocleista djalonensis

Cat. : Catechic

Gal. : Gallic

B : Bouchardat

D : Dragendorff

$+:$ Presence of metabolite

- : Absence of metabolite

Hypoglycemic effect of aqueous extracts of the three selected plants in normoglycemic rats

Effect of a single dose each of aqueous extract at concentration of $90 \mathrm{mg}$ / ml

In figure 1, the evolution of the blood glucose level in each test lot of rats after a single oral administration was observed, i.e $2 \mathrm{ml} / 100 \mathrm{~g}$ of b.w of each aqueous extract at single concentration of $90 \mathrm{mg} / \mathrm{ml}$ and of the control substances (distilled water and glibenclamide at $0.25 \mathrm{mg} / \mathrm{ml}$ ) relative to basal blood glucose.

According to the curve of the control with distilled water only Lot 1), the decrease recorded during the 4 hours is not significant ( $p>0.05)$. In fact, the blood glucose level goes from $105 \pm 0.17$ to $104 \pm 0.20 \mathrm{mg} / \mathrm{dl}$, a decrease of $1 \%$ compared to the basal blood glucose level.

These results show that water does not cause a significant decrease in blood glucose levels in normal glycemic rats by single gavage during the 4 hour period.

The baseline antidiabetic curve (Lot 2) shows a significant $(\mathrm{p}<0.01)$ decrease in basal blood glucose in rats from the first hour. Blood glucose levels decreased from $102 \pm 0.12$ to $57 \pm 0.09 \mathrm{mg} / \mathrm{dl}$, a significant decrease of 
$44.12 \%$. This significant decrease of $44.12 \%$ remains constant until the 4 th hour.

This shows that glibenclamide in single-dose causes a significant decrease in blood glucose in normal rats during the 4-hour period.

The curve of the aqueous extract of AGECO (Lot test 1) shows a nonsignificant decrease $(p>0.05)$ of blood glucose levels in the rat. Blood glucose increase from $106 \pm 0.15$ to $109 \pm 0.09 \mathrm{mg} / \mathrm{dl}$ in the first hour, an increase of $2.83 \%$ and finished at $97 \mathrm{mg} / \mathrm{dl}$ in the fourth hour, a decrease of $8.49 \%$.

From this result, it shows that the aqueous extract of AGECO does not significantly lower blood glucose levels in normal glycemic rats.

With the aqueous extract of ANTDJ (Lot test 3), an increase in the basal blood glucose level from $103 \pm 0.07$ to $110 \pm 0.10 \mathrm{mg} / \mathrm{dl}$ was observed from the thirtieth minute before a gradual and significant decrease is reached at the 4th hour. The blood glucose level increased to $82 \pm \mathrm{mg} / \mathrm{dl}$ at the end of the experimental time, blood glucose decreased significantly by $19.42 \%$.

The total aqueous extract of ANTDJ significantly decreased the blood glucose levels in normoglycemic rats.

The BIDPI curve (Lot test 2 ) shows a significant decrease $(\mathrm{P}<0.01)$ of basal blood glucose levels in rats from the 1 st hour. The blood glucose level decreases from $103 \pm 0.12$ to $88 \pm 0.20 \mathrm{mg} / \mathrm{dl}$, a significant decrease of $14.56 \%$ in the first hour. By the 4th hour this decrease continued and goes down to $68 \pm 0,18 \mathrm{mg} / \mathrm{dl}$ which is a significant decrease of $33,58 \%$. These results show that the aqueous total extract of BIDPI causes a gradual and significant decrease in normoglycemic rats.

This analysis shows that the three aqueous extracts reduce blood glucose levels in normoglycemic rats at a single concentration of $90 \mathrm{mg} / \mathrm{ml}$ with a significant decrease for aqueous ANTDJ and BIDPI extracts. The decrease observed with the aqueous extract of BIDPI is $33.58 \%$ against $44.12 \%$ for the reference molecule.

From this experiment, the use of the single concentration of $90 \mathrm{mg} /$ $\mathrm{ml}$ shows a significant decrease in blood glucose. The aqueous extract of Bidens pilosa presented the best activity. 


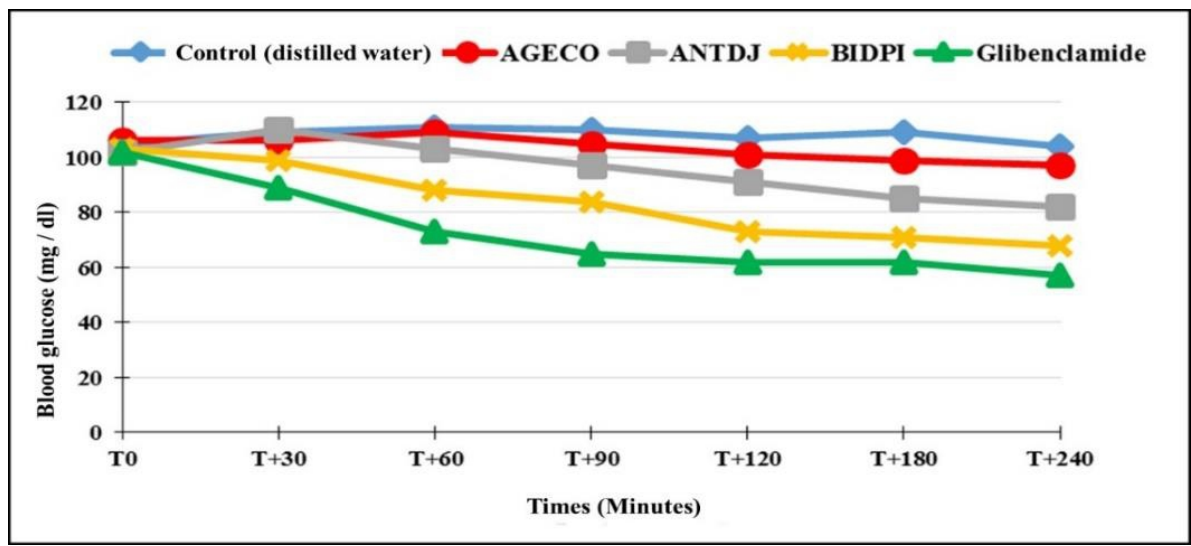

AGECO : Ageratum conyzoides

BIDPI : Bidens pilosa

ANTDJ : Anthocleista djalonensis

Figure 1: Evolution of blood glucose after administration of aqueous extracts of the three plants at a single concentration of $90 \mathrm{mg} / \mathrm{ml}$

\section{Effect of aqueous extract of Ageratum conyzoides (AGECO) at different concentrations compared to controls}

Figure 2 shows the variations in blood glucose levels of rats after oral administration at different concentrations $(70,90$ and $110 \mathrm{mg} / \mathrm{ml})$ of Ageratum conyzoides (AGECO), glibenclamide (test lots) or distilled water ( control lot).

The blood glucose levels of control rats receiving only distilled water did not vary significantly $(\mathrm{p}>0.05)$ throughout the duration of this study (4 hours). It remained at $104 \pm 3 \mathrm{mg} / \mathrm{ml}$.

Glibenclamide (reference antidiabetics molecule), at a concentration of $0.25 \mathrm{mg} / \mathrm{ml}$, causes a decrease in the glycemia of the treated rats. This hypoglycemia is significant.

With the concentrations ( 70 and $90 \mathrm{mg} / \mathrm{ml}$ ) of the aqueous extract of AGECO (lots 3a, 3b), no significant effect was observed ( $p>0.05$ ) on the glycemia of the treated animals. On the other hand, with the concentration of $110 \mathrm{mg} / \mathrm{ml}$ (Lot 3c), there was a slight decrease in the glycemia of the treated rats. This hypoglycemia is however not significant. 


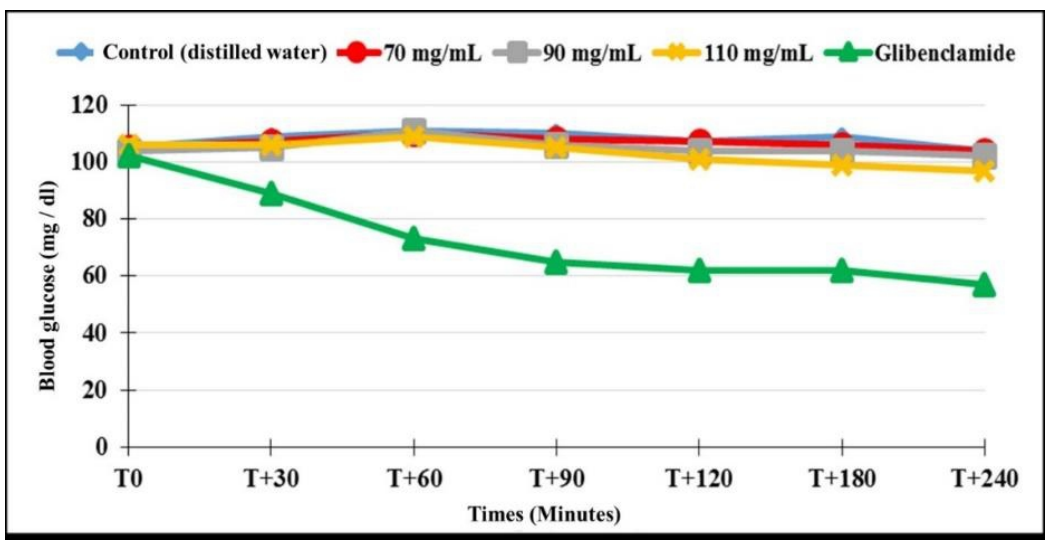

Figure 2: Evolution of glycemia after administration of the aqueous extract of Ageratum conyzoides at different concentrations

\section{Effect of aqueous extract of Bidens pilosa (BIDPI) at different concentrations compared to controls}

Figure 3 shows the changes in blood glucose levels of rats after oral administration at different concentrations $(70,90$ and $110 \mathrm{mg} / \mathrm{ml})$ of Bidens pilosa (BIDPI) (lots $4 \mathrm{a}, 4 \mathrm{~b}$ and $4 \mathrm{c}$ ), glibenclamide (lot 2 ) or distilled water (lot 1).

The blood glucose levels of control rats receiving only distilled water did not vary significantly $(\mathrm{p}>0.05)$ throughout the duration of this experiment (4 hours). It remained at $104 \pm 3 \mathrm{mg} / \mathrm{ml}$.

Glibenclamide (reference molecule), at a concentration of $0.25 \mathrm{mg} /$ $\mathrm{ml}$, causes a decrease in the glycemia of the treated rats. This hypoglycemia is significant.

A decrease in blood glucose was observed in the rats treated with the aqueous extract of BIDPI at different concentrations. This hypoglycemia is only significant $(\mathrm{p}<0.05)$ at the concentration of $70 \mathrm{mg} / \mathrm{ml}, 90$ minutes after treatment and gradually increases throughout the time of the experiment. This hypoglycemia reached a variation of $19 \mathrm{mg} / \mathrm{dL}$, a decrease of $18.4 \%$.

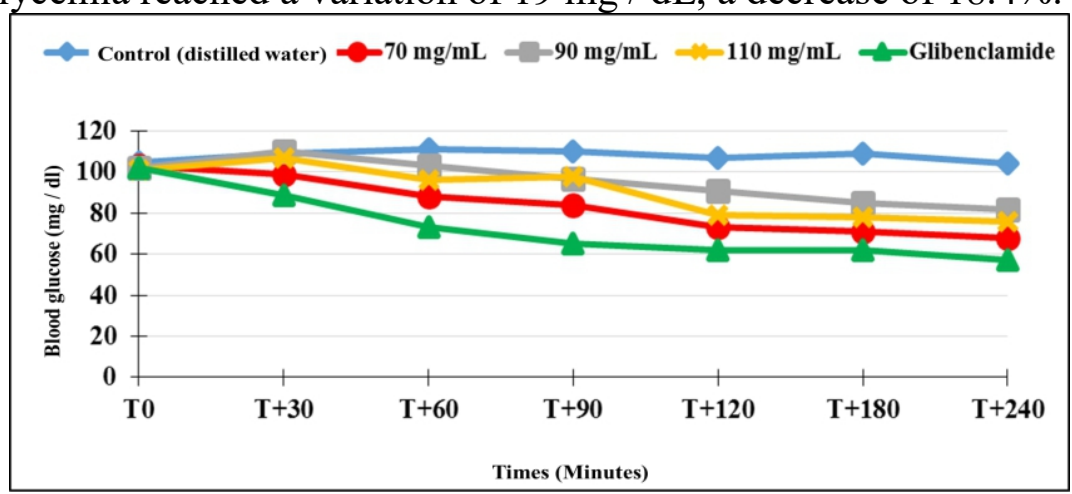

Figure 3: Evolution of glycemia after administration of the aqueous extract of Bidens pilosa at different concentrations 


\section{The Effect of the aqueous extract of Anthocleista djalonensis (ANTDJ) at different concentrations compared to controls}

Figure 4 shows the variations in blood glucose levels of rats after oral administration at different concentrations (70, 90 and $110 \mathrm{mg} / \mathrm{ml}$ ) of Anthocleista djalonensis (ANTDJ), glibenclamide (test lots) or distilled water (control lot).

The blood glucose levels of control rats receiving only distilled water did not vary significantly $(p>0.05)$ throughout the duration of this study (4 hours). It remained at $104 \pm 3 \mathrm{mg} / \mathrm{ml}$.

Glibenclamide (reference molecule), at a concentration of $0.25 \mathrm{mg} /$ $\mathrm{ml}$, causes decrease in the glycemia of the treated rats. This hypoglycemia is significant.

The aqueous extract at different concentrations of Anthocleista djalonensis (ANTDJ) induces a dose-dependent decrease in blood glucose levels in the treated rats. This hypoglycemia is not significant for each concentration. The best decrease is observed with the concentration of $110 \mathrm{mg}$ $/ \mathrm{ml}$ (Lot 5c).

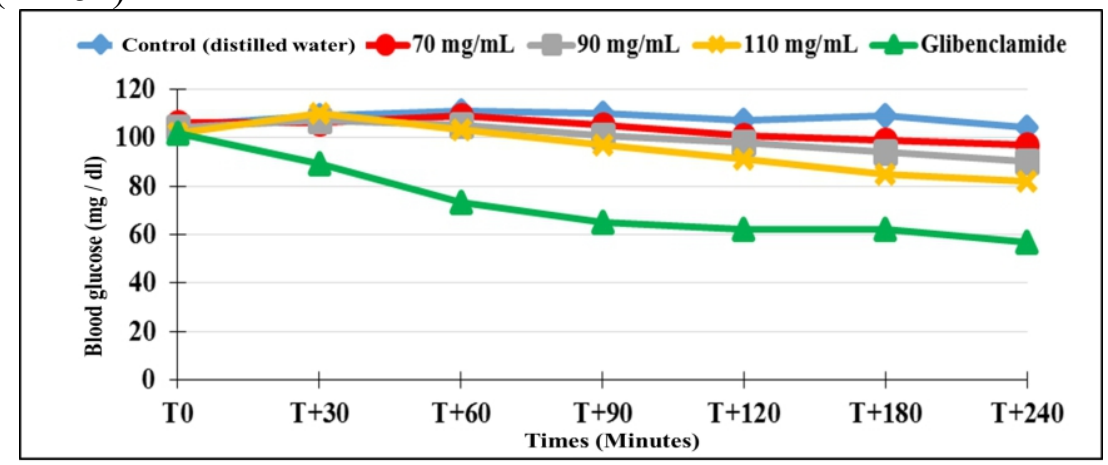

Figure 4: Evolution of glycemia after administration at different concentrations of the aqueous extract of Anthocleista djalonensis

\section{Discussion}

Phytochemical scanning showed the presence of chemical groups in the plant species studied. Phytochemical analysis of plant extracts is a preliminary step and of great importance since it reveals the presence of constituents known by their physiological activities and possessing medicinal properties (Zohra, 2013).

The phytochemical scanning highlighted the presence of polyphenols, flavonoids, tannins (catechins and gallic), saponosides and alkaloids, compounds with multiple medicinal properties, including glycemic regulation in diabetics. Indeed, the presence of alkaloids, flavonoids and tannins in the different species analyzed is an important indicator for the hypoglycemic or antidiabetic activity for these plant species. Guerci et al. (2001) demonstrated by their work that these secondary metabolites are endowed with this activity. 
The presence of these secondary metabolite could justify the use of these plants in the treatment of diabetes by the traditional medicine. According to Jouzier and Berké (2012), tannic substances extracted from Eucalyptus globulus (Myrtaceae) and fruits of Terminalia catappa (Combretaceae) possess valuable hypoglycemic properties and exhibit antidiabetic activity. These authors have shown that the bean pod (Phaseolus vulgaris, Fabaceae) or pod is rich in tannins and flavonoids that have the property of slowing down the absorption of sugars in the intestine, which limits and regulates their passage in the blood, especially avoiding the peak level of hyperglycemic after meals.

In addition, several authors including Huang et al. (2004); Kim et al. (2006); Mangambu et al. (2014) revealed that polyphenols and flavonoids are generally recognized as having hypoglycemic effects. Areej et al. (2012) confirmed the hypoglycemic effect of flavonoids. Aswathy and Jessykutty (2017) revealed in their study that flavonoids and saponins have antidiabetic activity. Quercetin is an important flavonoid known to possess a vast array of pharmacological activities. Quercetin suppressed the glucose level, reduce plasma cholesterol and triglycerides significantly and increased their hepatic glucokinase activity probably by enhancing the insulin release from pancreatic islets of the diabetic rats (Vessal et al., 2003).

The search for the hypoglycemic effect of the aqueous extract of each plant in normal glycemic rats showed a decrease in blood glucose. This decrease is due to the weak or strong presence of natural chemical compounds in plant extracts. This effect was compared to that of glibenclamide $5 \mathrm{mg} / \mathrm{kg}$, which is a hypoglycemic reference molecule. The sharp decrease in blood glucose is closer to that obtained with the extracts of Anthocleista djalonensis and Bidens pilosa. Indeed, Kroa et al. (2016) reported the hypoglycaemic properties of the aqueous extract of stem bark of Anthocleista djalonensis at a concentration of $2500 \mathrm{mg} / \mathrm{kg}$ body weight in treated rabbits. With the aqueous extract of Bidens pilosa, a better reduction of blood sugar is obtained. This decrease is very significant and comparable to the effect observed with glibenclamide. This study showed that the aqueous extract of Bidens pilosa contains hypoglycemic substances because it acts like glibenclamide which is a sulphonylurea. Indeed, sulfonylureas have been reported to induce hypoglycaemia in normoglycemic rats by stimulating insulin production through pancreatic beta cells, thus promoting the storage of glycogen in the liver (Somani et al., 2008). Gebreyohannis et al., 2014). The substances contained in the aqueous extracts of plants and particularly the extract of Bidens pilosa could be responsible for the pharmacological activities of these extracts. In fact, substances such as polyphenols and flavonoids are generally recognized as having hypoglycemic effects (Kim et al., 2006, Mangambu et al., 2014). 


\section{Conclusion}

The phytochemical study of the aqueous extracts of Ageratum conyzoides, Anthocleista djalonensis and Bidens pilosa revealed the presence of chemical compounds such as polyphenols, flavonoids, tannins (catechics and gallic), saponosides and alkaloids, chemical compound having multiple medical properties, including glycemic control in diabetics. The aqueous extract of each plant caused a decrease in blood glucose levels in normal glycemic rats. The aqueous extract of Bidens pilosa induces a significant dosedependent hypoglycemia. The study reveals that the aqueous extracts of the three plants have a hypoglycemic potential with a better activity with the aqueous extract of Bidens pilosa, which justifies their use in traditional medicine in the treatment of diabetes. However, in order to be closer to the realities practiced in the traditional medicine, a preparation based on these three plants could be considered as well as the evaluation of its antidiabetic activity.

\section{References:}

1. Areej M., Al-Taweel S.P., Ghada A.F., Saleh Ibrahim A. \& Kamal El Tahir E.H., 2012. New flavane gallates isolated from the leaves of Plicosepalus curviflorus and their hypoglycemic activity. Fitoterapia, $83: 1610-1615$.

2. Aswathy T.S. \& Jessykutty P.C., 2017. Antidiabetic phyto resources: A review. Journal of Medicinal Plants Studies, 5(3) : 165-169.

3. Fah L., Klotoé J.R., Dougnon V., Koudokpon H., Fanou V.B.A., Dandjesso C. \& Loko F., 2013. Étude ethnobotanique des plantes utilisées dans le traitement du diabète chez les femmes enceintes à Cotonou et Abomey-Calavi (Bénin). Journal of Animal \& Plant Sciences, 18(1) : 2647-2658.

4. Gebreyohannis T., Shibeshi W. \& Asres K., 2014. Effects of Solvent Fractions of Caylusea abyssinica (Fresen.) Fisch. \& Mey. on Blood Glucose Levels of Normoglycemic, Glucose Loaded and Streptozotocin-induced Diabetic Rodents. Journal of Natural Remedies, 14 : 67-75.

5. Ghourri M., Zidane L. \& Douira A., 2013. Usage des plantes médicinales dans le traitement du Diabète Au Sahara marocain (Tan Tan). Journal of Animal \&Plant Sciences, 17(1) : 2388-2411.

6. Guerci B., Bohme P., Kearney-Schwartz A., Zannad F. \& Drouin P., 2001. Endothelial dysfunction and type 2 diabetes. Diabetes Metab, 27 : 436-447.

7. Huang D.J., Lin C.D., Chen H.J. \& Lin Y.H., 2004. Antioxidant and antiproliferative activities of sweet potato (Ipomoea batatas (L.) Lam 
'Tainong 57') constituents. Botanical Bulletin-Academia Sinica, 45 : 179-186.

8. Jayakar B. \& Suresh B., 2003. Antihyperglycaemic effect of Aporosa lindleyana in normal and alloxan induced diabetic rats. Journal of Ethnopharmacology, 84 (2-3) : 247-249.

9. Jouzier E. \& Berké B., 2012. Diabète et Philatélie II - Plantes hypoglycémiantes. Bulletin de la Société de Pharmacologie de Bordeaux, 151(1-4), 141-170.

10. Kim S.H., Hyun S.H. \& Choung S.Y., 2006. Anti-diabetic effect of cinnamon extract on blood glucose in $\mathrm{db} / \mathrm{db}$ mice. Journal of Ethnopharmacology, 104(1-2) : 119-123.

11. Kroa E., Doh S.K., Soko Y.N., Yohou K.S., Koulaï O.J.-J.D., Gbogbo M., N'Guessan K., Aka J. \& Kouassi D., 2016. Effet de l'extrait aqueux de l'écorce de tige de Anthocleista djalonensis A. Chev. (Gentianaceae) sur la glycémie des lapins. International Journal of Biological and Chemical Sciences, 10(2) : 552-558.

12. Lebri M., 2016. Bioactivité d'extraits de Abrus precatorius Linn une plante de la pharmacopée ivoirienne : étude phytochimique, activités antidiabétique et cytotoxique. Thèse de Doctorat Unique, Université Félix HOUPHOUËT-BOIGNY, Abidjan, Côte d'Ivoire.179p.

13. OCDE, 2001.-Ligne directrice de l'OCDE pour les essais de produits chimiques de la toxicité orale aiguë - méthode par classe de toxicité aiguë, p 1-5.

14. Mangambu M.J.de.D., Mushagalusa K.F. \& Kadima N.J., 2014. Contribution à l'étude phytochimique de quelques plantes médicinales antidiabétiques de la ville de Bukavu et ses environs (Sud-Kivu, R.D. Congo). Journal of Applied Biosciences, 75 : 6211-6220.

15. N'Doua L.A.R., Abo K.J.C, Aoussi S., Gbogbo M., Yapo A.P. \& Ehile E.E., 2015. Effets hypoglycémique et antihyperglycemique de l'extrait éthanolique $70 \%$ de racines de Rauvolfia vomitoria afzel (Apocynaceae). European Scientific Journal, 11(6) : 176-190.

16. Ndomou M., Djidjou P.K., Moise Ayong M.N, Gouado I. \& Clergé Tchiegang C., 2014. Evaluation de l'activité antidiabétique des extraits de feuilles de Gnetum africanum et Gnetum bulchozzianum (Gnétacées). Sciences, Technologies et Développement, 15 : 60-65.

17. N'Guessan K., Fofié N'G.B.Y. \& Zirihi G.N., 2011. Effect of aqueous extract of Terminalia catappa leaves on the glycaemia of rabbits. Journal of Applied Pharmaceutical Science, 1 : 59-64.

18. Somani R.S. \& Singhai A.K., 2008. Hypoglycaemic and antidiabetic Activities of Seeds of Myristica fragrans in Normoglycaemic and Alloxan-induced Diabetic Rats. Asian Journal Experimental Sciences, 22 : 95-102. 
19. Vessal M., Hemmati M. \& Vasei M., 2003. Hypoglycemic effects of quercetinin streptozocin-induced diabetic rats, Comparative Biochemistry and Physiology. Toxicology and Pharmacology; 135: 357-364.

20. WHO, 2011. Diabète. Aide-mémoire N³12, septembre 2011.

21. WHO, 2002. Stratégie de l'OMS pour la Médecine traditionnelle pour 2002-2005., WHO/EDM/TRM/2002.1, Genève, 63p.

22. Zirihi G.N., Kra A.K.M. \& Guédé-Guina F., 2003. Évaluation de l'activité antifongique de Microglossa pyrifolia (Lamarck) O. Kuntze (Asteraceae) «PYMI » sur la croissance in vitro de Candida albicans. Revue de Médecine et de Pharmacopées Africaines, 17 : 11-18.

23. Zohra M., 2013. Étude Phytochimique et Activités Biologiques de quelques Plantes médicinales de la Région Nord et Sud-Ouest de l'Algérie. Thèse de Doctorat en Biologie, Faculté des Sciences, Département de Biologie Moléculaire et Cellulaire, Algérie, 170p. 